\title{
Technology-Based Changes of International Division of Labor in Recent Decades (Analysis Based on Selected Economies)
}

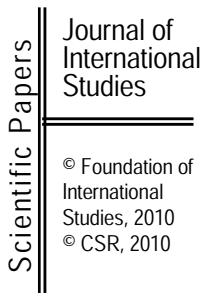

\author{
Dr Marcin Gryczka \\ Department of Foreign Trade \\ Faculty of Economics and Management \\ University of Szrzecin \\ gryczka@,wneiz.pl
}

\begin{abstract}
One of the undeniable feature of the contemporary international division of labor is increasing importance of ITC technologies and social capital, which allow the economy to be more competitive due to arising many connections to the global information networks. Based on conducted research it seems that a straightforward distinction between most developed, post-industrial economies and other economies on different, but lower stages of development, is simply obsolete. First and foremost, some developing countries are gaining on importance in international trade of high-tech products and knowledgeintensive business services (China and India are the most evident examples). On the other hand, these countries have become more and more effective competitors to developed countries in so called creative industries. This is partly caused by foreign direct investments flowed in especially during two past decades, but also is a consequence of social and educational policy leading to development of networked human capital, a substantial asset in the modern global economy. In a way such progress of developing countries under scrutiny in this article should be considered as an indication for Eastern European countries, such Poland and Ukraine, which are technologically backward on course for knowledge-based economy creation.
\end{abstract}

Keywords: international division of labor, knowledge-based economy, creative economy.

JEL classification: L01, O14, P2.

\section{Introduction}

For almost three last decades one could observe an unconceivable boom in Chinese economy, and the undeniable evidence of this phenomenon has been not only a recordbreaking gross domestic product change in this period, but a high-speed increasing importance of China in the international trade. According to the preliminary WTO data for 2009, China has already overtaken Germany as the world's leading merchandise exporter, accounting for almost $10 \%$ of world exports, and is second to the United States on the import 
side (the U.S. share in world merchandise imports is $13 \%$ compared to China's $8 \%$ - see WTO 2010, p. 6). Furthermore, another countries from the developing countries group, i.e. Brazil, the Russian Federation and India (together with China known as BRIC countries) are playing a much more increasing role in world economy at the present time. It seems that for the two former the vast natural resource stocks and growing raw materials dependence of many developed countries were the main incentives for this advancement, but the progress of Chinese and Indian economies has sourced primarily from foreign direct investments inflow driven by the well-thought-out economic policy.

This success of the biggest Asian economies can be derived from - among others still unfulfilled internal demand, especially for manufactured goods and commercial services, low costs of labor force and consistent educational policy leading to development of human capital resources. Of course, it's impossible to disregard the most essential problems, such still increasing socio-economic discrepancies between rural and urban areas, natural environment pollution, human and intellectual property rights violations, but for some time the abandonment of specialization in traditional and labor-intensive goods fabrication for capital-intensive manufactured goods (China) and services (India) is a quite visible and steady process. It could be considered as a certain contradiction to a quite common opinion, according to which only low-tech goods manufacturing based on outdated technology is transferred to the fast developing and industrializing countries. For that reason, the main objective of this article is to show and to analyze the evident changes occurring in the contemporary international division of labor, which have been caused not only by the progress of economic integration and globalization, but could be judged as direct effects of the knowledge and technology dissemination on global scale as well. Due to editorial and statistical data availability limitations, the analysis applies only to the selected time series (generally 1990-2008), and research concerning the changing role of BRIC countries (especially China and India) in contemporary global economy is conducted in comparison to the selected developed and transition economies (where applicable).

\section{Advances of BRIC countries in global economy}

It seems that any discussion about the progress of BRIC countries in global economy should begin from the general analysis of gross domestic product growth rates. According to the United Nations data (UNCTAD 2010, pp. 422-428), annual average growth rates of real GDP of developing, transition and developed economies in 1992-2007 amounted to 5.0, 2.7 and 2.5 percent, respectively. Looking more closely at the outcomes of BRIC economies in the same period, one can notice that annual average growth rate of Chinese real GDP amounted to 9.5 per cent, in case of India, the Russian Federation and Brazil - 6.5, 2.6 and 2.7, respectively. In other words, in 1992-2007 Chinese and Indian economies grew at much faster pace than developed economies, especially members of OECD. Moreover, according to the data for 2008-2009 (WTO 2010, p.6), annual percentage change of real GDP in 2008 for the most developed countries was far below the world average of $1.6 \%$, in comparison to $0.4 \%$ for United States, $0.7 \%$ for EU-27 and $-1.2 \%$ for Japan, and the situation got even worse in 2009 - again all three regions registered declines larger than the world average of $-2.3 \%$ (2.4, -4.2 and -5 per cent, respectively). China and India constituted a positive exception to this trend caused by global financial crisis, because in 2008-2009 their GDP growth rate dropped only relatively slightly (from 9.0 to 8.5 per cent in China, and from 7.3 to 5.4 per cent in India). Judging by this and the similar (in direction) trade developments for these countries, the structural changes had made in Chinese and Indian economies in the last decades allowed to overcome the present crisis without any severe and direct consequences. 
Table 1. Real gross domestic product (GDP) per capita for selected economies, 1980-2008

\begin{tabular}{|c|c|c|c|c|c|c|c|c|}
\hline & 1980 & 1985 & 1990 & 1995 & 2000 & 2005 & 2008 & $\begin{array}{c}\text { Change } \\
1990=100\end{array}$ \\
\hline World & 3786 & 3953 & 4187 & 4320 & 4756 & 5123 & 5444 & 130 \\
\hline Developed economies & 15513 & 17006 & 19165 & 20248 & 22923 & 24496 & 25594 & 134 \\
\hline Transition economies & 3475 & 4137 & 2773 & 1633 & 1829 & 2484 & 3054 & 110 \\
\hline Developing economies & 820 & 855 & 947 & 1118 & 1283 & 1547 & 1797 & 190 \\
\hline $\begin{array}{l}\text { Newly industrialized } \\
\text { economies }\end{array}$ & 1320 & 1583 & 2178 & 2884 & 3229 & 3744 & 4132 & 190 \\
\hline \multicolumn{9}{|c|}{ Real GDP per capita (in 1990 U.S. dollars) } \\
\hline China & 173 & 268 & 361 & 606 & 876 & 1333 & 1765 & 489 \\
\hline India & 267 & 310 & 379 & 441 & 534 & 689 & 841 & 222 \\
\hline Korea, Republic of & 3050 & 4110 & 6137 & 8604 & 10251 & 12504 & 13913 & 227 \\
\hline Poland & 1868 & 1770 & 1694 & 1862 & 2434 & 2851 & 3386 & 200 \\
\hline Russian Federation & $\mathrm{n} / \mathrm{a}$ & $\mathrm{n} / \mathrm{a}$ & $\mathrm{n} / \mathrm{a}$ & 2382 & 2611 & 3603 & 4443 & $187^{*}$ \\
\hline Ukraine & $\mathrm{n} / \mathrm{a}$ & $\mathrm{n} / \mathrm{a}$ & $\mathrm{n} / \mathrm{a}$ & 844 & 797 & 1205 & 1451 & $172 *$ \\
\hline \multicolumn{9}{|c|}{ Percentage of developed economies' real GDP per capita } \\
\hline China & 1.1 & 1.6 & 1.9 & 3.0 & 3.8 & 5.4 & 6.9 & 366 \\
\hline India & 1.7 & 1.8 & 2.0 & 2.2 & 2.3 & 2.8 & 3.3 & 166 \\
\hline South Korea & 19.7 & 24.2 & 32.0 & 42.5 & 44.7 & 51.0 & 54.4 & 170 \\
\hline Poland & 12.0 & 10.4 & 8.8 & 9.2 & 10.6 & 11.6 & 13.2 & 150 \\
\hline Russian Federation & $\mathrm{n} / \mathrm{a}$ & $\mathrm{n} / \mathrm{a}$ & $\mathrm{n} / \mathrm{a}$ & 11.8 & 11.4 & 14.7 & 17.4 & $148^{*}$ \\
\hline Ukraine & $\mathrm{n} / \mathrm{a}$ & $\mathrm{n} / \mathrm{a}$ & $\mathrm{n} / \mathrm{a}$ & 4.2 & 3.5 & 4.9 & 5.7 & $136^{*}$ \\
\hline
\end{tabular}

* $1995=100$

Source: author's calculations based on UNCTAD database.

If we examine the data concerning real gross domestic product per capita (table 1), the similar, but even more distinct trends are distinguishable. Albeit the developed economies achieved the highest real GDP per capita (what was predictable and in a sense understandable), during two last decades the most significant change affected developing and newly industrialized countries - between 1990 and 2008 the real GDP per capita increased in China almost fivefold, and in India and South Korea more than doubled. The outcomes of Poland, Russia and Ukraine were much worse, especially when examining their real GDP per capita in comparison to developed economies' values. In period in question (1990-2008) percentage of developed economies' real GDP per capita increased in China from 1.9 to 6.9, but in other countries (i.e. India, South Korea, Poland, Russia and Ukraine) this growth was much smaller and quite comparable - in range from 36 per cent (Ukraine) to 70 per cent (South Korea). Of course, it's worthy emphasizing that only South Korea has managed to reach at least the half of developed economies' real GDP per capita level. 
Table 2. Selected economies' GDP composition by sector, 1970-2008

\begin{tabular}{|c|c|c|c|c|c|c|c|}
\hline & Sector* & 1970 & 1980 & 1990 & 2000 & 2008 & $\begin{array}{c}\text { Change } \\
(1970=100)\end{array}$ \\
\hline \multirow{3}{*}{ World } & A & 13.2 & 8.1 & 5.6 & 3.6 & 4.0 & 30 \\
\hline & I & 36.9 & 38.1 & 33.3 & 29.1 & 30.1 & 82 \\
\hline & $\mathrm{S}$ & 49.9 & 53.8 & 61.1 & 67.3 & 65.9 & 132 \\
\hline \multirow{3}{*}{ Developed economies } & $\overline{\mathrm{A}}$ & 5.0 & 3.9 & 2.8 & 1.7 & 1.5 & 31 \\
\hline & I & 38.0 & 36.1 & 31.9 & 27.0 & 25.5 & 67 \\
\hline & $\mathrm{S}$ & 57.1 & 60.0 & 65.3 & 71.3 & 73.0 & 128 \\
\hline \multirow{3}{*}{ Germany } & A & $\mathrm{n} / \mathrm{a}$ & $\mathrm{n} / \mathrm{a}$ & 1.5 & 1.3 & 0.9 & $n / a$ \\
\hline & I & $\mathrm{n} / \mathrm{a}$ & $\mathrm{n} / \mathrm{a}$ & 37.3 & 30.3 & 30.2 & $n / a$ \\
\hline & $\mathrm{S}$ & $\mathrm{n} / \mathrm{a}$ & $\mathrm{n} / \mathrm{a}$ & 61.2 & 68.5 & 69.0 & $n / a$ \\
\hline \multirow{3}{*}{ France } & A & 7.5 & 4.7 & 3.8 & 2.8 & 2.0 & 27 \\
\hline & I & 35.6 & 32.7 & 26.6 & 22.9 & 20.4 & 57 \\
\hline & $\mathrm{S}$ & 56.9 & 62.6 & 69.6 & 74.3 & 77.6 & 136 \\
\hline \multirow{3}{*}{ Japan } & A & 6.3 & 3.6 & 2.5 & 1.7 & 1.4 & 22 \\
\hline & I & 45.9 & 39.1 & 38.4 & 31.1 & 28.8 & 63 \\
\hline & $\mathrm{S}$ & 47.7 & 57.2 & 59.1 & 67.2 & 69.7 & 146 \\
\hline \multirow{3}{*}{ Poland } & A & 13.7 & 13.8 & 9.2 & 5.0 & 4.5 & 33 \\
\hline & I & 52.0 & 51.9 & 46.0 & 31.7 & 31.0 & 60 \\
\hline & $\mathrm{S}$ & 34.3 & 34.3 & 44.8 & 63.3 & 64.4 & 188 \\
\hline \multirow{3}{*}{ United Kingdom } & $\mathrm{A}$ & 2.9 & 2.1 & 1.8 & 1.0 & 0.9 & 31 \\
\hline & I & 42.6 & 40.7 & 34.0 & 27.2 & 23.5 & 55 \\
\hline & $\mathrm{S}$ & 54.6 & 57.2 & 64.2 & 71.8 & 75.6 & 139 \\
\hline \multirow{3}{*}{ United States } & A & 2.9 & 2.4 & 1.9 & 1.0 & 1.1 & 36 \\
\hline & I & 33.8 & 32.9 & 27.5 & 23.6 & 21.9 & 65 \\
\hline & $\mathrm{S}$ & 63.3 & 64.6 & 70.6 & 75.4 & 77.1 & 122 \\
\hline \multirow{3}{*}{ Developing economies } & $\overline{\mathrm{A}}$ & 38.4 & 19.4 & 14.8 & 10.3 & 9.8 & 25 \\
\hline & I & 27.4 & 41.1 & 36.8 & 36.3 & 40.2 & 147 \\
\hline & $\mathrm{S}$ & 34.1 & 39.5 & 48.4 & 53.4 & 50.0 & 146 \\
\hline \multirow{3}{*}{ China } & A & 35.3 & 30.2 & 26.0 & 15.2 & 11.6 & 33 \\
\hline & I & 40.2 & 48.2 & 39.7 & 46.4 & 48.3 & 120 \\
\hline & $\mathrm{S}$ & 24.5 & 21.6 & 34.3 & 38.4 & 40.1 & 164 \\
\hline \multirow{3}{*}{ India } & A & 43.5 & 36.8 & 30.0 & 23.2 & 19.0 & 44 \\
\hline & I & 20.3 & 24.2 & 27.6 & 26.4 & 28.6 & 141 \\
\hline & $\mathrm{S}$ & 36.3 & 39.0 & 42.4 & 50.4 & 52.4 & 144 \\
\hline \multirow{3}{*}{ South Korea } & $\mathrm{A}$ & 27.9 & 15.5 & 8.6 & 4.6 & 3.1 & 11 \\
\hline & I & 24.4 & 34.3 & 38.9 & 38.4 & 37.7 & 154 \\
\hline & $\mathrm{S}$ & 47.7 & 50.2 & 52.5 & 57.0 & 59.2 & 124 \\
\hline \multirow{3}{*}{ Transition economies } & A & 16.5 & 11.4 & 19.9 & 10.3 & 6.1 & 37 \\
\hline & I & 45.7 & 46.1 & 44.8 & 36.3 & 36.4 & 80 \\
\hline & $\mathrm{S}$ & 37.8 & 42.6 & 35.3 & 53.4 & 57.5 & 152 \\
\hline \multirow{3}{*}{ Russian Federation } & $\mathrm{A}$ & $\mathrm{n} / \mathrm{a}$ & $\mathrm{n} / \mathrm{a}$ & $\mathrm{n} / \mathrm{a}$ & 6.7 & 4.9 & $n / a$ \\
\hline & I & $\mathrm{n} / \mathrm{a}$ & $\mathrm{n} / \mathrm{a}$ & $\mathrm{n} / \mathrm{a}$ & 37.9 & 36.1 & $n / a$ \\
\hline & $\mathrm{S}$ & $\mathrm{n} / \mathrm{a}$ & $\mathrm{n} / \mathrm{a}$ & $\mathrm{n} / \mathrm{a}$ & 55.4 & 59.0 & $n / a$ \\
\hline \multirow{3}{*}{ Ukraine } & A & $\mathrm{n} / \mathrm{a}$ & $\mathrm{n} / \mathrm{a}$ & $\mathrm{n} / \mathrm{a}$ & 16.8 & 7.4 & $n / a$ \\
\hline & I & $\mathrm{n} / \mathrm{a}$ & $\mathrm{n} / \mathrm{a}$ & $\mathrm{n} / \mathrm{a}$ & 37.6 & 34.0 & $n / a$ \\
\hline & $\mathrm{S}$ & $\mathrm{n} / \mathrm{a}$ & $\mathrm{n} / \mathrm{a}$ & $\mathrm{n} / \mathrm{a}$ & 45.5 & 58.6 & $n / a$ \\
\hline
\end{tabular}

* A - agriculture, I - industry, $\mathrm{S}$ - services

Source: author's calculations based on UNCTAD database.

As commonly known, in post-industrial economy the relative importance of manufacturing lessens and that of services, information, and research grows (Kallinikos 2006). In other words, the higher income of the nation, the higher share of services in country's total development and GDP. ${ }^{1}$ Although the process of production transfer to the

\footnotetext{
${ }^{1}$ Because most service jobs cannot be filled by machines, services are more expensive relative to agricultural
} 
industrializing (developing) countries, which are able to continue manufacturing at lower costs, is often attributed to the developed nations as the United States and most Western European countries, the decreasing share of agriculture and industry sectors in GDP can be noticed in some developing countries as well. Generally, in the world economy an agriculture sector contribution to GDP decreased between 1970 and 2008 more than threefold (from 13.2 to 4.0 per cent), and that of industry sector fell only by 6 percentage points. Compared to this, service sector contribution to GDP increased in the same period by 32 per cent, having reached in 2008 share of almost 66 per cent (table 2). As expected, developed countries are distinguished by the highest share of service sector in GDP (Eichengreen B., Gupta P. 2009, pp. 16-19), which for example in France and the United States exceeded 77 per cent (in Poland service sector contribution raised nearly twofold).

As we look closer to the developing countries' GDP composition by sector, a quite symptomatic phenomenon is decreasing share of agriculture sector, although in 2008 it was still over sixfold higher than that observed in developed countries. In South Korea an industry sector share grew particularly in seventies and eighties of the last century, but service sector contribution to GDP raised only by one-fifth in the period 1970-2008. On the other hand, the fast growing service sector share in India's and especially China's GDP (by 64 and 44 percentage points, respectively) could be considered as some evidence for their gradual transformation to post-industrial economies (it should be stressed that in 2008 service sector contribution to India's GDP was comparable to that of South Korea, Russia and Ukraine, and higher than developing countries' average).

\section{Growing importance of developing countries in the international trade}

Based on above considerations one can suppose that a increasing role of service sector should be also noticed in the international trade. Although between 1980 and 2009 services' share in total world exports was gradually increasing (from 15.2 to 21.4 per cent - see table 3 ), the rate of commercial services export growth was much higher than that of merchandise exports. Based on data presented in table 3, total world exports in period 1980-2009 increased about 6.5 times, merchandise exports - almost sixfold, but commercial services exports more than ninefold. It seems that one of the most important factors having influenced this process is technology and knowledge diffusion in international scale, supported by many activities undertook by both developed and newly industrialized countries for creation of knowledge based economies.

and industrial goods, further increasing the share of services in GDP. The lower mechanization of services also explains, why employment in the service sector continues to grow while employment in agriculture and industry declines due to technological progress that increases labor productivity and eliminates jobs. Finally the service sector replaces the industrial sector as the leading sector of the economy (Soubbotina T.P. 2000, p. 52). 
Table 3. World merchandise and commercial services exports (current billions of U.S. dollars), 1980-2009

\begin{tabular}{|c|c|c|c|c|c|c|c|c|}
\hline & 1980 & 1985 & 1990 & 1995 & 2000 & 2005 & 2008 & 2009 \\
\hline $\begin{array}{l}\text { Total merchandise and } \\
\text { commercial services exports, } \\
\text { of which: }\end{array}$ & 2399 & 2336 & 4229 & 6336 & 7938 & 12972 & 19901 & 15459 \\
\hline Merchandise exports & 2034 & 1954 & 3449 & 5164 & 6456 & 10489 & 16097 & 12147 \\
\hline $\begin{array}{l}\text { Commercial services } \\
\text { exports }\end{array}$ & 365 & 382 & 780 & 1172 & 1482 & 2483 & 3804 & 3312 \\
\hline High-tech exports & $\mathrm{n} / \mathrm{a}$ & $\mathrm{n} / \mathrm{a}$ & 363 & 671 & 1089 & 1499 & 1740 & $\mathrm{n} / \mathrm{a}$ \\
\hline $\begin{array}{l}\text { Percentage of manufactures } \\
\text { exports }\end{array}$ & $n / a$ & $n / a$ & 15.2 & 18.0 & 23.2 & 20.5 & 16.6 & $n / a$ \\
\hline $\begin{array}{l}\text { Other commercial services } \\
\text { exports }\end{array}$ & 127 & 141 & 293 & 465 & 661 & 1219 & 1946 & 1754 \\
\hline $\begin{array}{l}\text { Percentage of commercial } \\
\text { services export }\end{array}$ & 34.8 & 37.0 & 37.5 & 39.6 & 44.6 & 49.1 & 51.2 & 53.0 \\
\hline
\end{tabular}

Source: author's calculations based on WTO and COMTRADE databases.

Growing contribution of high-tech products to total manufactures exports (which reached 20 per cent in the beginning of present decade) can be recognized as a confirmation of knowledge usage success. Furthermore, an evidence of increasing human and social capital role (not only in postindustrial, developed economies, but in some developing countries as well) is a growing share of other commercial services ${ }^{2}$ in total services exports. During the period under scrutiny other commercial services exports reached almost 2 US\$ billions, what indicates the most significant growth (by 14 times), and this group share in total commercial services exports was sustainably increasing from 35 per cent in 1980 to 53 per cent in 2009 . While world exports of other commercial services decreased by 10 per cent in 2009 , this group has not been as badly affected by the last economic downturn as merchandise and transportation services (WTO 2010, pp. 6-7).

\footnotetext{
${ }^{2}$ According to the WTO, other commercial services group includes communications services, construction, insurance services, financial services, computer and information services, royalties and license fees, personal, cultural, and recreational services, and other business services, mainly professional and technical services (much of above is highly knowledge- and capital-intensive services) (WTO 2009, pp. 165-166).
} 
Table 4. High-tech exports of selected economies, 1990-2008

\begin{tabular}{|l|r|r|r|r|r|}
\cline { 2 - 6 } \multicolumn{1}{c|}{} & \multicolumn{1}{c|}{1990} & \multicolumn{1}{c|}{1995} & \multicolumn{1}{c|}{2000} & \multicolumn{1}{c|}{2005} & \multicolumn{1}{c|}{2008} \\
\hline France & 26.0 & 42.0 & 58.0 & 69.7 & 93.2 \\
Germany & 39.2 & 57.1 & 82.7 & 142.5 & 162.4 \\
Japan & 65.6 & 110.1 & 127.4 & 122.7 & 123.7 \\
Poland & $\mathrm{n} / \mathrm{a}$ & 0.4 & 0.8 & 2.7 & 7.2 \\
United Kingdom & 34.6 & 52.2 & 69.9 & 82.8 & 61.8 \\
United States & 90.9 & 128.8 & 196.7 & 190.9 & 231.1 \\
\hline Brazil & 1.2 & 1.2 & 5.9 & 8.0 & 10.6 \\
Russian Federation & $\mathrm{n} / \mathrm{a}$ & $\mathrm{n} / \mathrm{a}$ & 4.2 & 3.7 & 5.1 \\
India & 0.3 & 1.0 & 1.6 & 3.4 & 6.5 \\
China & $\mathrm{n} / \mathrm{a}$ & 13.2 & 40.8 & 214.2 & 381.3 \\
South Korea & 10.8 & 29.6 & 54.0 & 83.5 & $110.6 *$ \\
Ukraine & $\mathrm{n} / \mathrm{a}$ & $\mathrm{n} / \mathrm{a}$ & 0.5 & 0.9 & 1.5 \\
\hline \multicolumn{5}{|c|}{ Percentage of country's merchandise exports } \\
\hline France & 16.1 & 18.7 & 24.3 & 20.0 & 20.2 \\
Germany & 11.1 & 12.9 & 18.0 & 17.0 & 13.5 \\
Japan & 23.8 & 26.1 & 28.3 & 22.5 & 17.9 \\
Poland & $n / a$ & 2.7 & 3.3 & 3.8 & 5.2 \\
United Kingdom & 23.6 & 27.3 & 32.1 & 28.0 & 19.3 \\
United States & 33.0 & 30.8 & 33.7 & 29.9 & 27.1 \\
\hline Brazil & 7.1 & 4.8 & 18.6 & 12.8 & 12.0 \\
Russian Federation & $n / a$ & $n / a$ & 17.2 & 8.1 & 6.5 \\
India & 2.4 & 4.3 & 4.8 & 4.7 & 5.7 \\
China & $n / a$ & 10.5 & 18.6 & 30.6 & 28.7 \\
South Korea & 17.8 & 25.9 & 34.8 & 32.3 & $26.2 *$ \\
Ukraine & $n / a$ & $n / a$ & 5.1 & 3.7 & 3.2 \\
\hline
\end{tabular}

* 1997

Source: author's calculations based on COMTRADE database.

Though high-tech products are still exported for the most part by developed countries such the United States, Japan and Germany, during two last decades a growing importance of China and South Korea can be observed in this field. It is particularly visible, if we look at the percentage share of that goods in country's merchandise exports (table 4). Between 1990 and 2008 the contribution of high-tech products to merchandise exports increased only slightly in France and Germany (for comparison, in Poland this share changed barely from 2.7 per cent in 1995 to 7.2 per cent in 2008), but considerably dropped in Japan, the United States and United Kingdom (by 25, 18, and 18 per cent, respectively). In the biggest post-soviet states, i.e. the Russian Federation and Ukraine, this drop was even deeper - by 62 per cent in the former, and by 37 per cent in the latter (only in present decade). On the other hand, rest of the BRIC countries and newly industrialized economy of South Korea experienced a quite significant growth of high-tech exports, especially as regards to their share in merchandise 
exports. During two last decades this commodity group's exports share increased in Brazil by 70 per cent, in India by almost 140 per cent, in South Korea by 47 per cent, and in China by 173 per cent. Among commodity groups, which gained most in importance in high-tech exports of these countries, were telecommunications equipment (South Korea, China, Brazil), automatic data processing equipment (China), semiconductors and electronic integrated circuits (South Korea), pharmaceutical products (India), aircrafts and associated equipment (Brazil). This qualitative high-tech export composition change can be recognized as another indirect evidence of high-technology manufacturing transfer not only to the newly industrialized countries (so called South-East Asian Tigers), but to a considerable degree to other developing countries as India, Brazil and especially - China (Lemoine, Unal-Kesenci 2004).

Similarly as in high-tech exports, the most developed countries, i.e. European Union 27, the United States and Japan, have the highest share in other commercial services exports (in 2008, these regions accounted for 49.5, 15.3 and 4.6 per cent of total other commercial services exports, respectively), but fourth and fifth place in leading exporters of other commercial services ranking 2008 was occupied by India and China (with shares of 4.1 and 3.5 per cent, respectively). Moreover, top 15 exporters of other commercial services included also the Russian Federation (10th place with share of 1.2 per cent) and Brazil (14th place with share of 0.9 per cent - WTO 2009, p. 133). Compared to them, share of Poland reached barely to 0.7 per cent, and Ukraine - to 0.2 per cent (table 5). On the other hand, BRIC countries and Poland accounted for the highest change in other commercial services export in period 19902008, which can be interpreted as en evidence of increasing role of these countries in knowledge- and capital-intensive services exports. For example, in 2008 the Russian Federation recorded the highest increase in exports, rising by 34 per cent, and mirroring the growth rate of 2007. Business, professional and technical services, which account for more than half of the country's exports of other commercial services, were mainly exported to the European Union, the United States and Switzerland (WTO 2009, p. 117).

Table 5. Exports of other commercial services, 1990-2008

\begin{tabular}{|l|r|r|r|r|r|r|}
\cline { 2 - 7 } \multicolumn{1}{c|}{} & \multicolumn{1}{c|}{1990} & \multicolumn{1}{c|}{1995} & \multicolumn{1}{c|}{2000} & \multicolumn{1}{c|}{2005} & \multicolumn{1}{c|}{2008} & $\begin{array}{c}\text { Change } \\
(1990=100)\end{array}$ \\
\hline \multicolumn{1}{c|}{1} & \multicolumn{1}{c}{ Exports (current billions of U.S. dollars) } \\
\hline World & 292.5 & 464.5 & 660.6 & 1218.5 & 1946.3 & 665 \\
\hline France & 29.7 & 35.1 & 30.8 & 49.2 & 66.3 & 223 \\
Germany & 21.5 & 35.7 & 41.1 & 90.0 & 142.6 & 664 \\
Japan & 20.0 & 38.2 & 39.3 & 59.7 & 88.8 & 443 \\
Poland & 1.0 & 5.3 & 2.3 & 4.5 & 12.7 & 1259 \\
United Kingdom & 24.7 & 41.0 & 77.7 & 142.0 & 208.9 & 847 \\
United States & 45.1 & 78.6 & 129.7 & 197.8 & 292.8 & 649 \\
\hline Brazil & 1.0 & 2.4 & 5.7 & 7.9 & 17.6 & 1808 \\
Russian Federation & $\mathrm{n} / \mathrm{a}$ & 2.5 & 2.6 & 9.8 & 23.7 & $959 *$ \\
India & 2.1 & 2.3 & 10.6 & 39.0 & 79.4 & 3797 \\
China & 1.3 & 6.3 & 10.2 & 29.2 & 67.2 & 5152 \\
South Korea & 2.8 & 7.7 & 9.2 & 14.0 & 21.5 & 763 \\
Ukraine & $\mathrm{n} / \mathrm{a}$ & 0.5 & 0.5 & 1.3 & 3.9 & $777^{*}$ \\
\hline \hline
\end{tabular}




\begin{tabular}{|c|c|c|c|c|c|c|}
\hline 1 & 2 & 3 & 4 & 5 & 6 & 7 \\
\hline \multicolumn{7}{|c|}{ Percentage of world's exports of other commercial services } \\
\hline France & 10.2 & 7.5 & 4.7 & 4.0 & 3.4 & 33 \\
\hline Germany & 7.3 & 7.7 & 6.2 & 7.4 & 7.3 & 100 \\
\hline Japan & 6.9 & 8.2 & 6.0 & 4.9 & 4.6 & 67 \\
\hline Poland & 0.3 & 1.1 & 0.3 & 0.4 & 0.7 & 233 \\
\hline United Kingdom & 8.4 & 8.8 & 11.8 & 11.7 & 10.7 & 127 \\
\hline United States & 15.4 & 16.9 & 19.6 & 16.2 & 15.0 & 97 \\
\hline Brazil & 0.3 & 0.5 & 0.9 & 0.6 & 0.9 & 300 \\
\hline Russian Federation & $\mathrm{n} / \mathrm{a}$ & 0.5 & 0.4 & 0.8 & 1.2 & $240^{*}$ \\
\hline India & 0.7 & 0.5 & 1.6 & 3.2 & 4.1 & 586 \\
\hline China & 0.4 & 1.4 & 1.6 & 2.4 & 3.5 & 875 \\
\hline South Korea & 1.0 & 1.7 & 1.4 & 1.2 & 1.1 & 110 \\
\hline Ukraine & $\mathrm{n} / \mathrm{a}$ & 0.1 & 0.1 & 0.1 & 0.2 & $200 *$ \\
\hline
\end{tabular}

* $1995=100$

Source: author's calculations based on WTO database.

While the post-industrialized economies still dominate in exports of financial services, insurance services, royalties and license fees, personal, cultural and recreational services, the growing importance of China and India is more and more noticeable in exports of construction, computer and information services, communication services and other business services. According to the WTO data for 2007, India took second place among the major exporters of computer and information services (with exports value of US\$27.7 billion) and fourth place in classification of major communications services exporters (with exports value of US\$ 2.3 billion). China has become one of the world's leaders as regards to construction (third place in 2007, with exports value of US\$ 5.4 billion) and other business services (third place in 2007, with exports value of US\$ 40.4 billion, WTO 2009, pp. 137-155). It seems that the one of the most important reason of this process is direct foreign investments inflow resulting in creation of many branch offices and BPOs (for example, many IT-related BPOs located in India and cooperating with U.S.-based multinationals - Corona at al. 2006, pp. 2187), backed up by educational and social policy aimed for increasing supply of well-educated labor force not only for high-tech manufacturing, but for service sector as well. 


\section{Developed economies $\square$ Developing economies $\quad$ Economies in $\mathrm{t}$}

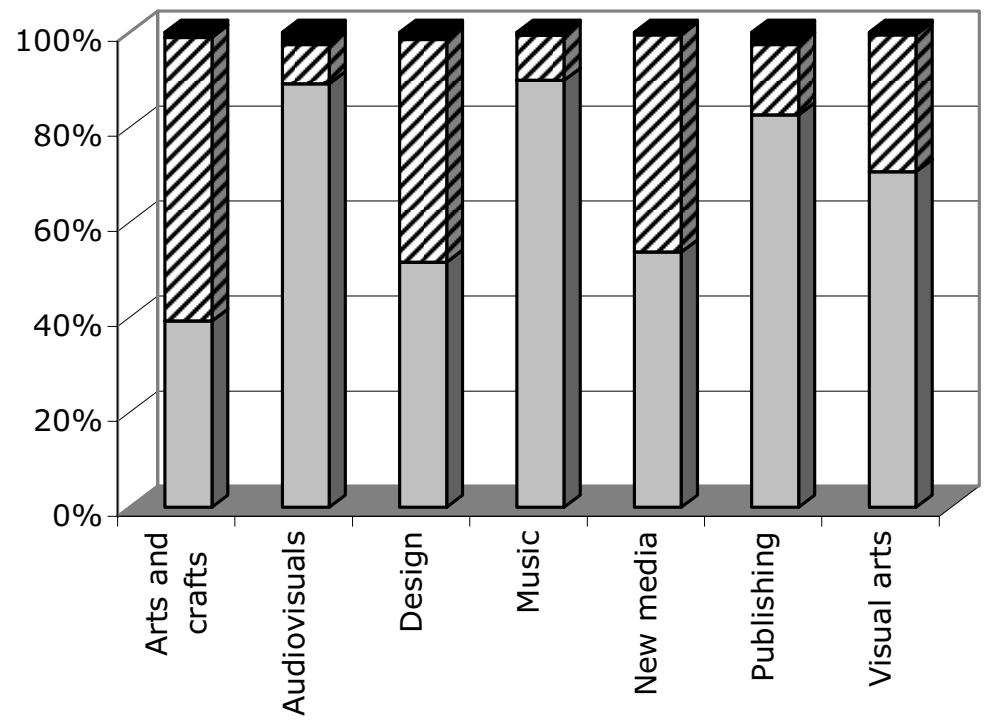

Figure 1. Share of economic groups in world exports of creative goods, 2005 Source: UNCTAD.

\section{Creative economy - the next step in the international division of labor}

The term "creative economy" appeared in 2001 in John Howkins' book about the relationship between creativity and economics (Howkins J. 2001). Although his use of this concept is broad, covering fifteen creative industries extending from arts to the wider fields of science and technology, according to UNCTAD "creative economy" is an evolving concept based on creative assets potentially generating economic growth and development, and embraces economic, cultural and social aspects interacting with technology, intellectual property and tourism objectives (UNCTAD 2008, p. 15). Because of many similarities between concepts of knowledge-based economy and creative economy (among others, the leading role of knowledge, information and social capital), the predominance of developed economies in world trade of creative goods is noteworthy. In 2005, in total exports of creative goods was about 90 per cent for music and audiovisuals, around 80 per cent for publishing/printed media, 70 per cent for visual arts, and over 50 per cent for new media and design. Figure 1 shows the importance of creative industries for both developed and developing economies. Furthermore, these trade data mirror the fact that the high-growth subgroups of creative industries with higher value added such as audiovisuals and new media are exported mainly by advanced economies. For developing economies, arts and crafts constitutes the most important group of creative products, accounting for 60 per cent of their share in the world market for creative-industry goods (design and new media also have great potential). This upward trend in exports of creative goods from developing economies is caused mainly by substantial increases in the design subgroup, with exports rising from US\$ 42.9 billion in 1996 to US\$ 102.4 billion in 2005, reflecting mainly the growth in China. Moreover, in period 2000-2005 the world exports of creative goods increased by 47 per cent, reaching US\$ 335.5 billion, but a comparison of this flow between developed economies and 
China (growth by 42 and 115 per cent, respectively - UNCTAD 2008, pp. 107-108) justifies the statement that also in this field China (and in the near future probably other fastdeveloping economies, for instance India) is going to become a strong competitor for developed economies, what can be treated as a further proof of fundamental changes taking place in the international division of labor.

\section{Conclusions}

As commonly known, post-industrial economies are often distinguished by vestigial agriculture and declining manufacturing sector (resulting in de-industrialization), a large service sector, and a growing importance of information and communication technologies. Data presented in this article allow to make a conclusion that in the contemporary world economy not only the most developed countries such the United States, Japan and part of Western European countries can be recognized as post-industrial ones, but a few developing economies (mostly newly industrialized and BRIC countries) are aspiring to such a title as well. Observed in a few last decades their economic successes have come mostly from the huge internal markets, unparalleled human resources and a long-term policy oriented to attracting as much foreign direct investments as possible. China increases its global domination as leading merchandise exporter (unquestionably the special economic zones are one of the most important spurs for this trend), but also becomes more and more significant player in the international trade in high-tech products, knowledge-intensive business services and goods of creative industries' origin. On the other hand, Indian economy is more internally-oriented, but consistent social and educational policy has made possible a huge advance in attracting foreign investments in commercial services sector, especially in computer and information services. Compared to this two economies, recent economic achievements of other BRIC countries, Ukraine or even Poland seems to be meager and hardly confirm their probable aspirations to the group of knowledge-based, creative economies. Among potential, serious problems, which could possibly stop the economic catching-up process in BRIC countries, one must mention an increasing socio-economic stratification and digital divide between rural and urban areas (also observed in both Ukraine and Poland), and still unresolved issues concerning intellectual rights protection (Branstetter L.G. at al. 2006) and exports of counterfeited products, e.g. pharmaceuticals and integrated circuits by China. ${ }^{3}$

\section{References}

1. Branstetter L.G., Fisman R., Foley C.F. (2006). Do Stronger Intellectual Property Rights Increase International Technology Transfer? Empirical Evidence From U.S. Firm-Level Panel Data. "Quarterly Journal of Economics", volume 121 (1 Feb), pp. 321-349.

2. BSA (2010). Seventh Annual BSA/IDC Global Software Piracy Study. Business Software Alliance, Washington D.C.

3. Corona L., Doutriaux J., Mian S.A. (2006). Building Knowledge Regions in North America. Emerging Technology Innovation Poles. Edward Elgar, CheltenhamNorthampton.

4. Dachs B., Zahradnik G. (2008). Internationalisation of $R \& D$ in ICT. In Meijers H., Dachs B., Welfens P.J.J. (eds.), Internationalisation of European ICT Activities.

\footnotetext{
${ }^{3}$ According to the Business Software Alliance, while in period 2005-2009 software piracy rate of BRIC countries was steadily decreasing (from 81 to 71 per cent), commercial value of unlicensed software grew sharply from 6.8 to 14.5 billions of U.S. dollars (BSA 2010).
} 
Dynamics of Information and Communications Technology, pp. 157-185, Springer, Berlin-Heidelberg.

5. Eichengreen B., Gupta P. (2009). The two waves of service sector growth. National Bureau Of Economic Research, Working Paper 14968, Cambridge.

6. Howkins J. (2001). The Creative Economy: How People Make Money from Ideas. London, Penguin.

7. Kallinikos J. (2006). The Consequences of information. Institutional Implications of Technological Change. Edward Elgar, Cheltenham-Northampton.

8. Lemoine F., Unal-Kesenci D. (2004). Assembly Trade and Technology Transfer: The Case of China. "World Development", volume 32, issue 5, May 2004, pp. 829-850.

9. Soubbotina T.P. (2000). Beyond Economic Growth: Meeting The Challenges Of Global Development. The World Bank, Washington.

10. UNCTAD (2008). Creative Economy Report 2008. United Nations, New York and Geneva.

11. UNCTAD (2010). UNCTAD Handbook of Statistics 2009, United Nations, New York and Geneva.

12. WTO (2009). International Trade Statistics 2009, World Trade Organization, Geneva.

13. WTO (2010). World Trade 2009, Prospects For 2010, World Trade Organization Press Release no. 598, Geneva, 26 March 2010. 